\title{
PENGUKURAN KINERJA PORTOFOLIO OPTIMAL CAPITAL ASSET PRICING MODEL (CAPM) DAN ARBITRAGE PRICING THEORY (APT) (Studi Kasus : Saham-saham LQ45)
}

\author{
Dedi Baleo Pasaribu', Di Asih I Maruddani², Sugito ${ }^{3}$ \\ 1,2,3 Departemen Statistika, Fakultas Sains dan Matematika, Universitas Diponegoro \\ e-mail :maruddani@gmail.com
}

\begin{abstract}
Investing is placing money or funds in the hope of obtaining additional or specific gains on the money or funds. The capital market is one place to invest in the financial field of interest to investor. This is because the capital market gives investor the freedom to choose securities traded in the capital market in accordance with the wishes of investor. Investor are included in risk averter, that means investor will always try to avoid risk. To avoid risk, investor try to diversify their investment. Diversification concept commonly used is portfolio. To maximize the return to be earned, the investor will invest his funds into several stocks in order to earn a greater profit. Capital Asset Pricing Model(CAPM) is a balance model that describes the relation of a risk with return more simply because it uses only one variable to describe the risk. Arbitrage Pricing Theory (APT) is a balance model that used many risk variables to see the relation of risk and return. With both models will be obtained a portfolio with each constituent stock is four stocks selected from 45 stocks in the LQ45 index. To find out which portfolio is the best performed a performance analys is using the Sharpe index. From the measurement result, it is found that the best portfolio is the CAPM portfolio with composite stock is PTBA with inves tment weight of $0.467 \%$, BUMI with investment weight of $12.855 \%$, ANTM with investment weight of $53.077 \%$ and PPRO with investment weight of $33.601 \%$.
\end{abstract}

Keywords: LQ45, portfolio, Capital Asset Pricing Model (CAPM), Arbitrage Pricing Theory (APT), Sharpe Index

\section{PENDAHULUAN}

Investasi adalah menempatkan uang atau dana dengan harapan untuk memperoleh tambahan atau keuntungan tertentu atas uang atau dana tersebut (Kamaruddin, 2004). Pada saat ini pemerintah juga banyak membuat kebijakan untuk meningkatkan investasi di Indonesia. Hal ini dilakukan karena investasi dapat meningkatkan ekonomi suatu negara, laju pembangunan, lapangan kerja baru atau bahkan penambahan devisa. Selain memberi manfaat bagi pemerintah, investasi juga dapat memberi penghasilan tambahan atau jaminan di masa depan bagi masyarakat.

Pasar modal merupakan salah satu tempat sarana berinvestasi dalam bidang finansial yang menarik bagi investor. Hal ini disebabkan karena pasar modal memberikan kebebasan bagi investor untuk memilih sekuritas yang diperdagangkan dalam pasar modal sesuai dengan keinginan investor. Pasar modal juga menjanjikan tingkat pengembalian yang lebih besar kepada investor.

Untuk memaksimalkan pengembalian yang akan didapatkan, biasanya investor tidak hanya berinvestasi pada satu saham saja. Melainkan investor akan menginvestasikan dananya ke beberapa saham dengan tujuan agar mendapatkan keuntungan yang lebih besar nantinya. Maka dalam hal ini analisis portofolio diperlukan.

Ada berbagai model yang bisa digunakan dalam pembentukan portofolio. Penelitian ini model yang digunakan adalah Capital Asset Pricing Model (CAPM) dan Arbritage Pricing Theory (APT). CAPM adalah teori penilaian risiko dan keuntungan aset yang didasarkan pada nilai beta (Kamaruddin, 2004). Model CAPM merupakan model keseimbangan yang menggambarkan hubungan suatu risiko dengan return secara lebih sederhana karena hanya menggunakan satu variabel (beta) untuk menggambarkan risiko. 
Seperti halnya CAPM, APT menggambarkan hubungan antara risiko dan return, tetapi dengan asumsi dan prosedur yang berbeda. Model APT menggunakan banyak variabel pengukur risiko untuk melihat hubungan risiko dan return.

Berdasarkan metode CAPM dan APT akan dilakukan perhitungan kinerja dari kedua metode tersebut. Pengukuran kinerja bertujuan untuk mengetahui apakah portofolio yang dibentuk telah dapat meningkatkan kemungkinan tercapainya tujuan investasi. Metode pengukuran kinerja yang digunakan adalah The Sharpe Index. Indeks Sharpe ini relevan dipergunakan untuk investor yang menanamkan dananya pada portofolio tersebut, sehingga risiko portofolio dinyatakan dalam standar deviasi. Portofolio yang mempunyai rasio terbesar dinilai mempunyai kinerja yang terbaik.

\section{TINJAUAN PUSTAKA}

\subsection{Pasar Modal}

Pasar modal adalah pasar instrumen keuangan jangka pendek ataupun jangka panjang untuk diperjualbelikan baik dalam bentuk hutang maupun modal sendiri yang diterbitkan oleh pemerintah, public authorities dan perusahaan swasta. Menurut undangundang Republik Indonesia nomor 8 tahun 1995 tanggal 10 November 1995 menjelaskan pasar modal adalah kegiatan yang bersakutan dengan perdagangan umum dan perdagangan efek, perusahaan publik yang berkaitan dengan efek yang diterbitkannya, serta lembaga dan profesi yang berkaitan dengan efek (Azis et al., 2015).

\subsection{Investasi}

Investasi merupakan kegiatan menempatkan sejumlah dana yang dimiliki saat ini dengan harapan akan memperoleh keuntungan di masa mendatang. Bentuk investasi bisa dilakukan secara langsung maupun tidak langsung (Zulfikar, 2016).

\subsection{Saham}

Saham adalah tanda bukti memiliki perusahaan dimana pemiliknya disebut juga sebagai pemegang saham (shareholder atau stockholder) (Azis et al., 2015).

\subsection{Indeks Harga Saham}

Indeks harga saham adalah indikator atau cerminan pergerakan harga saham. Indeks merupakan salah satu pedoman bagi investor untuk melakukan investasi di pasar modal, khususnya saham (Azis et al., 2015). Pergerakan harga saham perlu diketahui bagi investor atau masyarakat, maka indeks harga saham merupakan salah satu yang memberikan informasi yang lebih lengkap.

\subsection{Return}

Return merupakan salah satu faktor yang memotivasi investor untuk berinvestasi karena return merupakan hasil yang diperoleh dari investasi (Jogiyanto, 2010). Return adalah imbalan atas keberanian investor menanggung risiko dengan kata lain return sebagai keuntungan atau kerugian suatu investasi dalam periode tertentu (Zulfikar, 2016).

Return didefinisikan sebagai berikut :

$$
R_{i, t}=\ln \left(\frac{P_{i, t}}{P_{i,(t-1)}}\right) \quad ; \mathrm{t}=1,2, \ldots, \mathrm{q}
$$

dengan $\mathrm{P}_{\mathrm{i}, \mathrm{t}}$ adalah harga asset ke-I pada waktu ke-t. 


\subsection{Risiko}

Risiko adalah suatu keadaan yang kemungkinan adanya kerugian yang akan terjadi dimasa mendatang (Zulfikar, 2016). Risiko juga dapat diartikan sebagai kenyataan yang tidak sesuai harapan. Investor perlu memahami risiko dalam bisnis karena semua jenis investasi yang ada memiliki risiko baik kecil maupun besar.

\subsection{Teori Portofolio}

Menurut J. Fred Weston dan Thomas E. Copeland (1992) dalam Azis et al. (2015) teori portofolio merupakan teori modern yang membahas tentang ketidakpastian dalam mengambil keputusan. Tujuannya adalah untuk mendiversifikasikan secara optimal sahamsaham yang dimiliki (portofolio efisien). Diversifikasi adalah membentuk portofolio melalui pemilihan kombinasi sejumlah aset sedemikian rupa hingga risiko dapat diminimalkan tanpa mengurangi return harapan (Tandelilin, 2010). Portofolio efisien merupakan portofolio yang dipilih dari sekian banyak pilihan untuk memaksimalkan keuntungan.

\subsection{Portofolio dengan Capital Asset Pricing Model (CAPM)}

CAPM merupakan model keseimbangan yang menggambarkan hubungan risiko dan return secara lebih sederhana, dan hanya menggunakan satu variabel (beta) untuk menggambarkan risiko (Zulfikar, 2016). Beta merupakan suatu pengukur volatilitas return suatu sekuritas atau return portofolio terhadap return pasar (Tandelilin, 2010). Berdasarkan teori Markowitz, masing-masing investor akan mendiversifikasikan portofolionya dan memilih portofolio yang optimal atas dasar preferensi investor terhadap return dan risiko. Secara umum, model persamaan untuk pembentukan portofolio sebagai berikut :

$E\left(R_{i}\right)$ : Expected return saham ke-i

$$
E\left(R_{i}\right)=R_{b r}+\beta_{i}\left(E\left(R_{m}\right)-R_{b r}\right) \quad ; \mathrm{i}=1,2, \ldots, \mathrm{n}
$$

$R_{b r} \quad:$ Return bebas risiko atau $\mathrm{Rbr}$

$E\left(R_{m}\right):$ Expected return pasar

$\beta_{i} \quad$ : Beta (ukuran risiko) sekuritas ke-i

$$
\beta_{\mathrm{i}}=\frac{\operatorname{cov}\left(\mathrm{R}_{i}, \mathrm{R}_{m}\right)}{\operatorname{var}\left(\mathrm{R}_{m}\right)} \quad ; \mathrm{i}=1,2, \ldots, \mathrm{n}
$$

$\operatorname{cov}\left(\mathrm{R}_{\mathrm{i}}, \mathrm{R}_{\mathrm{m}}\right) \quad$ : Kovarian antara return saham ke-i dan return pasar

$\operatorname{var}\left(\mathrm{R}_{\mathrm{m}}\right) \quad$ : Varian return pasar

Saham yang mempunyai beta lebih besar $1(>1)$ dikatakan memiliki risiko yang lebih besar dari tingkat risiko rata-rata pasar. Beta $=1$, artinya setiap satu persen perubahan return pasar maka return saham atau portofolio juga akan berubah sama besar mengikuti retrun pasar. Saham yang mempunyai nilai beta $<1$ dikatakan sebagai saham yang memiliki risiko di bawah rata-rata pasar (Jogiyanto, 2012).

\subsection{Bobot Portofolio dengan CAPM}

Seorang investor harus menentukan bobot investasi yang akan ditanamkan ke saham-saham agar mendapatkan portofolio yang optimal. Salah satu metode pembentukan portofolio optimal adalah Mean Variance Efficient Portofolio (MVEP) dengan cara mencari vektor pembobotan. Vektor pembobotan (w) yang dicari akan membentuk portofolio dengan varian yang minimun berdasarkan dua batasan (constraints) yaitu : 
1. Spesifikasi awal dari mean return ( $\mu$ p) harus tercapai yaitu wT $\mu$.

2. Jumlah proporsi dari portofolio yang terbentuk sama dengan 1 yaitu $\mathrm{wT} 1 \mathrm{~N}=1$, dimana $1 \mathrm{~N}$ adalah vektor 1 dengan dimensi $\mathrm{N}$ x 1 .

Dengan menggunakan fungsi Lagrange permasalahan optimalisasi dapat diselesaikan dengan persamaan :

$$
L=w^{T} \sum w+\lambda_{1}\left(\mu_{p}-w^{T} \mu\right)+\lambda_{2}\left(1-w^{T} 1_{N}\right)
$$

Dimana $L$ adalah fungsi Lagrange dan adalah faktor pengali Lagrange.

Kasus portofolio dengan varian efisien, tidak ada pembatasan pada mean portofolio ( $=0$ ), sehingga pembobotan pada MVEP adalah sebagai berikut :

$$
w=\frac{\sum^{-1} 1_{N}}{1_{N}^{T} \sum^{-1} 1_{N}}
$$

dengan $\sum^{-1}$ adalah invers matriks varian-kovarian (Maruddani dan Purbowati, 2009).

\subsection{Portofolio dengan Arbitrage Pricing Theory (APT)}

Arbitrage Pricing Theory (APT) merupakan salah satu alternatif teori model keseimbangan selain CAPM. Sama halnya dengan CAPM, APT menggambarkan hubungan antara risiko dan return, tetapi dengan menggunakan asumsi dan prosedur yang berbeda. Pada APT return sekuritas tidak hanya dipengaruhi oleh portofolio pasar karena adanya asumsi bahwa return harapan dari suatu sekuritas bisa dipengaruhi oleh beberapa sumber risiko lainnya (Tandelilin, 2010).

Pada model APT investor percaya bahwa return sekuritas akan ditentukan oleh sebuah model faktorial dengan $\mathrm{k}$ faktor risiko. Maka untuk mencari return aktual menggunakan rumus sebagai berikut :

$$
R_{i}=E\left(R_{i}\right)+b_{i 1} f_{1}+b_{i 2} f_{2}+\ldots+b_{i k} f_{k}+e_{i} \quad ; \mathrm{i}=1,2, \ldots, \mathrm{n} \text { dan } \mathrm{k}=1,2, \ldots, \mathrm{p}
$$

$\mathrm{R}_{\mathrm{i}} \quad$ : tingkat return aktual sekuritas ke $\mathrm{i}$

$\mathrm{E}\left(\mathrm{R}_{\mathrm{i}}\right)$ : return harapan untuk sekuritas $\mathrm{i}$

$\mathrm{f}_{\mathrm{k}} \quad$ : deviasi faktor sistematis $\mathrm{F}$ (faktor risiko) dari nilai yang diharapkan

$\mathrm{b}_{\mathrm{ik}} \quad$ : sensitivitas sekuritas i terhadap faktor $\mathrm{k}$

$\mathrm{e}_{\mathrm{i}} \quad$ : nilai error

Model faktorial di atas tidak memberikan penjelasan mengenai kondisi keseimbangan. Untuk itu persamaan di atas perlu diubah ke dalam model keseimbangan, sehingga return harapan untuk suatu sekuritas adalah:

$$
E\left(R_{i}\right)=R_{b r}+b_{i 1} \bar{F}_{1}+b_{i 2} \bar{F}_{2}+\ldots+b_{i k} \bar{F}_{k}
$$

$\mathrm{E}\left(\mathrm{R}_{\mathrm{i}}\right)$ : return harapan untuk sekuritas $\mathrm{i}$

$\mathrm{R}_{\mathrm{br}} \quad$ : return bebas risiko

$b_{i k} \quad$ : koefisien yang menunjukkan besarnya pengaruh faktor $k$ terhadap return sekuritas i

$\overline{\mathrm{F}}_{k} \quad$ : premi risiko untuk sebuah faktor $\mathrm{k}\left(\mathrm{E}\left(\mathrm{F}_{\mathrm{k}}\right)-\mathrm{R}_{\mathrm{br}}\right)$

\subsection{Bobot Portofolio Model APT}

Asumsi-asumsi portofolio yang arbitrase adalah (Azis et al., 2015) :

1. Portofolio arbitrase adalah portofolio yang tidak memerlukan dana tambahan dari investor. Jika wi menotasikan perubahan kepemilikan investor atas sekuritas i (dan juga proporsi sekuritas i pada portofolio arbitrase), portofolio arbitrase dapat ditulis sebagai berikut : 


$$
\sum_{i=1}^{n} w_{i}=0
$$

2. Portofolio arbitrase tidak memiliki sensitivitas terhadap faktor apa pun. Karena sensitivitas portofolio terhadap faktor merupakan rata-rata tertimbang sensitivitas sekuritas dari portofolio terhadap faktor tersebut, persyaratan portofolio arbitrase ini dapat ditulis :

$$
\sum_{i=1}^{n} w_{i} b_{i}=0
$$

3. Untuk melihat apakah suatu portofolio benar-benar merupakan portofolio arbitrase, harus ditentukan ekspektasi returnnya. Jika hasilnya positif maka memang itulah portofolio arbitrase. Secara matematis dapat ditulis :

$$
\sum_{i=1}^{n} w_{i} \bar{R}_{i}>0
$$

\subsection{Analisis Regresi}

Analisis regresi merupakan suatu teknik analisis yang mencoba menjelaskan bentuk hubungan antara dua peubah atau lebih khususnya hubungan antara peubah-peubah yang mengandung sebab akibat (Wibisono, 2009). Untuk mengetahui hubungan antara dua variabel atau lebih menggunakan metode persamaan linier. Bentuk umum persamaan linier adalah :

$$
Y=\alpha+\beta_{1} X_{1}+\beta_{2} X_{2}+\ldots+\beta_{k} X_{k}+e_{i} \quad ; \mathrm{k}=1,2, \ldots, \mathrm{p} \text { dan } e \square N\left(0, \sigma^{2}\right)
$$

Y : variabel dependen

a : konstanta

$\beta_{\mathrm{k}} \quad$ : koefisien variabel independen

$\mathrm{X}_{\mathrm{k}} \quad$ : variabel independen

\subsection{Uji Hipotesis Koefisien Regresi}

Uji hipotesis koefisien regresi dilakukan untuk menunjukan apakah variabel independen $X_{k}$ memberikan kontribusi secara signifikan terhadap model regresi atau tidak. Langkah-langkah analisis sebagai berikut :

1. Hipotesis

$\mathrm{H}_{0} \quad: \quad \beta \mathrm{k}=0$ (variabel bebas $\mathrm{Xk}$ tidak memberikan kontribusi yang signifikan terhadap model regresi)

$\mathrm{H}_{1} \quad: \beta \mathrm{k} \neq 0$ (variabel bebas $\mathrm{Xk}$ memberikan kontribusi yang signifikan terhadap model regresi)

2. Penentuan nilai kritis

Nilai kritis dalam pengujian hipotesis terhadap koefisien regresi dapat ditentukan dengan menggunakan tabel distribusi $\mathrm{t}$ dengan memperhatikan tingkat signifikansi $(\alpha)$, banyaknya sampel dan jumlah variabel yang digunakan Karena pengujian dua sisi, maka pada penentuan nilai kritis atau $t_{\text {tabel }}$ menggunakan $\frac{\alpha}{2}$ dengan derajat kebebasan $=\mathrm{n}-\mathrm{k}-1$.

3. Statistik Uji

$t_{\text {hitung }}=\frac{\hat{\beta}_{k}}{\sqrt{\operatorname{var}\left(\hat{\beta}_{k}\right)}}$ atau dengan melihat nilai sig. pada output

4. Kriteria Uji 
Tolak H0 jika $\left|t_{\text {hitung }}\right|>t_{\frac{\alpha}{2}, n-k-1}$ atau nilai sig. $<\alpha$

\subsection{Kine rja Portofolio}

Menurut Suad Husnan (1996) penilaian kinerja perlu dilakukan untuk mengetahui apakah pilihan investasi memberikan hasil terbaik atau tidak. The Sharpe Index merupakan salah satu metode untuk mengukur kinerja portofolio. The Sharpe Index menyatakan kinerja portofolio dihitung berdasarkan hasil bersih dari portofolio dengan tingkat bunga bebas risiko per unit risiko dengan diberi simbol Sp. Portofolio yang mempunyai rasio terbesar dinilai mempunyai kinerja terbaik. Sharpe dapat dihitung dengan formula sebagai berikut (Azis et al., 2015):

$$
S_{p}=\frac{\bar{R}_{p}-R_{b r}}{\sigma_{p}}
$$

$\operatorname{dimana} \bar{R}_{p}=\sum_{i=1}^{n}\left(w_{i}^{*} E\left(R_{i}\right)\right)$

$\mathrm{S}_{\mathrm{p}} \quad$ : Indeks Sharpe

$\overline{\mathrm{R}}_{\mathrm{p}} \quad$ : Rata-rata return portofolio

$\mathrm{R}_{\mathrm{br}} \quad$ : return bebas risiko dengan data SBI

$\sigma_{\mathrm{p}} \quad$ : standar deviasi dari return portofolio

\section{METODE PENELITIAN}

\subsection{Sumber Data dan Variabel Pe nelitian}

Data yang digunakan dalam penelitian ini adalah data sekunder, yaitu data saham bulanan yang terdaftar dalam indeks LQ45 periode Agustus 2017 sampai Januari 2018 yang diperoleh dari www.finance.yahoo.com dan periode data Desember 2015 sampai dengan Desember 2017. Penelitian ini menggunakan data return saham sebanyak 24 data.

\subsection{Tahapan Analis is Data}

1. Menghitung return setiap saham pada LQ45.

2. Menghitung return pasar.

3. Menghitung expected return pasar.

4. Menghitung nilai $\beta$ setiap saham pada LQ45.

5. Menghitung expected return setiap saham pada LQ45.

6. Seleksi saham menggunakan CAPM

7. Memilih saham terbaik pada LQ45 menggunakan CAPM

8. Melakukan analisis regresi untuk mengetahui return saham yang berpengaruh terhadap faktor risiko.

9. Menentukan bobot aset portofolio menggunakan metode Arbitrage Pricing Theory dan metode Capital Asset Pricing Model.

10. Melakukan analisis kinerja portofolio dengan menggunakan metode The Sharpe Index. 


\section{HASIL DAN PEMBAHASAN}

\subsection{Deskripsi Data dan Perhitungan Return Saham}

Data yang digunakan adalah data retrun saham dengan jumlah observasi sebanyak 24 data. Selain itu adapula data faktor yang digunakan adalah Suku Bunga Bank Indonesia (SBI), Indeks Harga Saham Gabungan (IHSG) dan kurs dollar. Setelah semua data didapatkan, langkah selanjutnya adalah menghitung return dari masing-masing saham Indeks LQ45 dan return Indeks Harga Saham Gabungan (IHSG).

\subsection{Pemilihan Saham Penyusun Portofolio Menggunakan CAPM}

Dalam pembentukan portofolio model CAPM, terlebih dahulu dihitung beta dari masing-masing saham $(\beta)$ dengan menggunakan rumus

$$
\beta_{\mathrm{i}}=\frac{\operatorname{cov}\left(\mathrm{R}_{i}, \mathrm{R}_{m}\right)}{\operatorname{var}\left(\mathrm{R}_{m}\right)} \quad ; \mathrm{i}=1,2, \ldots, 45
$$

$\beta$ suatu saham $=1$ berarti saham tersebut memiliki risiko yang sama dengan risiko rata-rata pasar. $\beta$ suatu saham $<1$ berarti saham tersebut memiliki risiko di bawah risiko rata-rata pasar. Sedangkan $\beta$ suatu saham $>1$ berarti saham tersebut memiliki risiko di atas risiko rata-rata pasar. Kemudian menghitung expected return dari masing-masing saham dengan menggunakan rumus

$$
E\left(R_{i}\right)=R_{b r}+\beta_{i}\left(E\left(R_{m}\right)-R_{b r}\right)
$$

Data $\mathrm{R}_{\mathrm{br}}$ yang digunakan adalah data Suku Bunga Bank Indonesia (SBI) bulan Desember 2017 yaitu sebesar 4,25\% sedangkan data $\mathrm{E}\left(\mathrm{R}_{\mathrm{m}}\right)$ yang digunakan adalah data Indeks Harga Saham Gabungan (IHSG).

\subsubsection{Saham Terbaik Model CAPM}

Saham-saham yang dipilih dalam portofolio ini adalah saham-saham yang memiliki risiko di bawah risiko rata-rata pasar $(\beta<1)$ oleh karena itu dalam penelitian ini akan diambil saham yang memiliki risiko di bawah rata-rata risiko pasar dan yang memiliki expected return terbesar dari masing-masing saham. Dalam penelitian ini akan diambil empat saham terbaik berdasarkan kriteria tersebut yang dapat dilihat pada Tabel 1 .

Tabel 1. Saham Terbaik Model CAPM

\begin{tabular}{|c|c|c|c|}
\hline NO & Kode Saham & Beta & Expected Return \\
\hline 1 & PTBA & $-7,5532$ & 0,2613 \\
\hline 2 & BUMI & $-1,9340$ & 0,0985 \\
\hline 3 & ANTM & $-0,8637$ & 0,0675 \\
\hline 4 & PPRO & $-0,7538$ & 0,0643 \\
\hline
\end{tabular}

\subsubsection{Pembentukan Bobot Optimal}

Dengan menggunakan bantuan program $\mathrm{R}$ pada lampiran 7, diperoleh hasil seperti pada Tabel 2.

Tabel 2. Bobot Optimal Masing-masing Saham

\begin{tabular}{|c|c|c|}
\hline No & Saham & Bobot \\
\hline 1 & PTBA & 0,00467 \\
\hline 2 & BUMI & 0,12855 \\
\hline 3 & ANTM & 0,53077 \\
\hline 4 & PPRO & 0,33601 \\
\hline
\end{tabular}


Berdasarkan Tabel 2 dapat diketahui bahwa investor akan menginvestasikan dananya sebesar 0,467\% ke saham PTBA, sebesar 12,855\% ke saham BUMI, sebesar 53,077\% ke saham ANTM dan 33,601\% ke saham PPRO.

\subsection{Pemilihan Saham Penyusun Portofolio Menggunakan APT}

Dalam pembentukan portofolio model APT, akan dicari return saham yang dipengaruhi oleh faktor risiko. Faktor yang digunakan dalam penelitian ini adalah Suku Bunga Bank Indonesia (SBI) dengan notasi $F_{1}$, Indeks Harga Saham Gabungan (IHSG) dengan notasi $\mathrm{F}_{2}$ dan kurs dollar dengan notasi $\mathrm{F}_{3}$.

\subsubsection{Analisis Regresi}

Analisis regresi digunakan untuk mencari pengaruh faktor terhadap return saham. Setelah dilakukan pengujian maka diperoleh saham-saham yang dipengaruhi oleh faktor yang dapat dilihat pada Tabel 3 .

Tabel 3. Saham yang Dipengaruhi oleh Faktor dengan Model Baru

\begin{tabular}{|c|c|c|c|c|c|}
\hline Saham & Beta 1 & Beta 2 & Beta 3 & Rbr & E(Ri) \\
\hline BRPT & -1.754 & & -6.955 & 0.0425 & 0.460452174 \\
\hline BMTR & & & -7.605 & 0.0425 & 0.372611681 \\
\hline MNCN & & & -7.172 & 0.0425 & 0.353816367 \\
\hline BBTN & & & -4.664 & 0.0425 & 0.244951135 \\
\hline ICBP & -0.559 & 1.048 & & 0.0425 & 0.049130151 \\
\hline SMGR & & 1.285 & & 0.0425 & 0.005278351 \\
\hline BBCA & & 1.351 & & 0.0425 & 0.003366578 \\
\hline ADHI & & 1.609 & & 0.0425 & -0.004106718 \\
\hline ASII & & 1.662 & & 0.0425 & -0.00564193 \\
\hline BBNI & & 1.786 & & 0.0425 & -0.009233747 \\
\hline BSDE & & 1.907 & & 0.0425 & -0.012738665 \\
\hline SMRA & & 2.162 & & 0.0425 & -0.020125062 \\
\hline EXCL & 1.130 & & & 0.0425 & -0.032267582 \\
\hline
\end{tabular}

Dalam penelitian ini dikarenakan tidak ada kriteria tertentu dalam memilih saham yang akan digunakan untuk portofolio maka peneliti akan memilih empat saham yang memiliki expected return terbesar dan memenuhi syarat pembentukan portofolio sehingga diperoleh saham yang terpilih adalah BRPT, BMTR, MNCN dan BBTN.

\subsubsection{Uji Hipotesis Koefisien Regresi}

Berdasrakan hasil uji signifikansi menggunakan software SPSS diperoleh hasil pada Tabel 4.

Tabel 4. Hasil thitung dan Nilai Sig.

\begin{tabular}{|l|c|c|}
\hline Saham & thitung $_{1}$ & Sig. \\
\hline BRPT & Untuk $F_{1}=-2,346$ & 0,029 \\
& Untuk $F_{3}=-2,299$ & 0,032 \\
\hline BMTR & Untuk $F_{3}=-3,439$ & 0,002 \\
\hline MNCN & Untuk $F_{3}=-2,720$ & 0,013 \\
\hline BBTN & Untuk $F_{3}=-3,908$ & 0,001 \\
\hline
\end{tabular}

Pada taraf signifikansi 5\% dapat disimpulkan bahwa saham BRPT variabel $\mathrm{F}_{1}$ dan $F_{3}$, BMTR variabel $F_{3}, M N C N$ variabel $F_{3}$ dan $B B T N$ variabel $F_{3}$ signifikan terhadap variabel dependen karena nilai sig. $<\alpha(0.05)$. 


\subsubsection{Asumsi Normalitas}

Tabel 5.

Berdasarkan hasil uji normalitas menggunakan software SPSS diperoleh hasil pada Tabel 5. Nilai Sig. Kolmogorov-Smirnov

\begin{tabular}{|l|c|}
\hline Saham & Sig. \\
\hline BRPT & 0,200 \\
\hline BMTR & 0,200 \\
\hline MNCN & 0,200 \\
\hline BBTN & 0,200 \\
\hline
\end{tabular}

Pada taraf signifikansi 5\% dapat disimpulkan bahwa residual BRPT, BMTR, MNCN dan BBTN berdistribusi normal karena nilai sig. $>\alpha(0.05)$.

\subsubsection{Asumsi Autokorelasi}

Berdasarkan hasil uji autokorelasi menggunakan software SPSS diperoleh hasil pada Tabel 6.

Tabel 6. Nilai Durbin-Watson

\begin{tabular}{|l|c|}
\hline Saham & Durbin-Watson \\
\hline BRPT & 1,729 \\
\hline BMTR & 1,614 \\
\hline MNCN & 2,272 \\
\hline BBTN & 1,749 \\
\hline
\end{tabular}

Pada taraf signifikansi 5\% dapat disimpulkan bahwa tidak terdapat autokorelasi pada residual BRPT, BMTR, MNCN dan BBTN karena nilai Durbin-Watson (d) berada diantara nilai dU dan 4-dU (dU < d $<4-d U)$.

\subsubsection{Asumsi Homoskedastisitas}

Berdasarkan hasil uji homoskedastisitas menggunakan software SPSS diperoleh hasil pada Tabel 7.

Tabel 7. Pengujian Glejser

\begin{tabular}{|l|l|c|}
\hline Saham & \multicolumn{1}{|c|}{ t } & Sig. \\
\hline BRPT & Untuk $F_{1}=-0,446$ & 0,660 \\
& Untuk $F_{3}=-1,2264$ & 0,220 \\
\hline BMTR & Untuk $F_{3}=0,627$ & 0,537 \\
\hline MNCN & Untuk $F_{3}=-0,110$ & 0,914 \\
\hline BBTN & Untuk $F_{3}=0,141$ & 0,889 \\
\hline
\end{tabular}

Pada taraf signifikansi $5 \%$ dapat disimpulkan bahwa asumsi homoskedasitas terpenuhi karena nilai Sig. untuk semua variable karena nilai sig. $>\alpha(0.05)$.

\subsubsection{Asumsi Multikolinie ritas}

Berdasarkan hasil uji multikolinieritas menggunakan software SPSS diperoleh hasil pada Tabel 8 .

Tabel 8. Nilai VIF

\begin{tabular}{|c|c|}
\hline Saham & VIF \\
\hline BRPT & Untuk F $F_{1}=1,014$ \\
& Untuk $F_{3}=1,014$ \\
\hline BMTR & Untuk $F_{3}=1,000$ \\
\hline
\end{tabular}




\begin{tabular}{|c|c|}
\hline $\mathrm{MNCN}$ & Untuk $F_{3}=1,000$ \\
\hline BBTN & Untuk $F_{3}=1,000$ \\
\hline
\end{tabular}

Karena nilai VIF untuk semua variabel lebih kecil dari 10 maka asumsi multikolinieritas terpenuhi.

\subsubsection{Saham Terbaik Model APT}

Saham-saham yang digunakan dalam portofolio ini adalah saham-saham yang dipengaruhi oleh faktor risiko yang telah ditentukan sebelumnya. Berdasarkan hasil analisis didapat saham yang dipengaruhi oleh faktor dapat dilihat pada Tabel 9.

Tabel 9. Saham Terbaik Model APT

\begin{tabular}{|c|c|c|c|c|c|c|c|}
\hline NO & Kode Saham & $\boldsymbol{\beta}_{\mathbf{1}}$ & $\boldsymbol{\beta}_{\mathbf{3}}$ & $\mathbf{F}_{\mathbf{1}}$ & $\mathbf{F}_{\mathbf{2}}$ & $\mathbf{F}_{\mathbf{3}}$ & $\mathbf{E}\left(\mathbf{R}_{\mathbf{i}}\right)$ \\
\hline 1 & BRPT & $-1,754$ & $-6,955$ & $-0,0662$ & $-0,0290$ & $-0,0434$ & 0,4605 \\
\hline 2 & BMTR & & $-7,605$ & $-0,0662$ & $-0,0290$ & $-0,0434$ & 0,3726 \\
\hline 3 & MNCN & & $-7,172$ & $-0,0662$ & $-0,0290$ & $-0,0434$ & 0,3538 \\
\hline 4 & BBTN & & $-4,664$ & $-0,0662$ & $-0,0290$ & $-0,0434$ & 0,2450 \\
\hline
\end{tabular}

\subsubsection{Pembentukan Bobot Optimal}

Berdasarkan Tabel 9 maka dapat dihitung bobot portofolio dengan persamaan sebagai berikut :

$$
\begin{gathered}
w_{1}+w_{2}+w_{3}+w_{4}=0 \\
-1,754 w_{1}=0 \\
-6,955 w_{1}+(-7,605) w_{2}+(-7,172) w_{3}+(-4,664) w_{4}=0
\end{gathered}
$$

Dengan menggunakan eliminasi Gauss Jordan dengan bantuan program R, didapat nilai $w_{1}=0, w_{2}=5,792148 w_{4}$ dan $w_{3}=-6,792148 w_{4}$, dalam penelitian ini $w_{4}$ dimisalkan sebesar 3\%. Maka didapat nilai $w_{1}$ sebesar $0 \%$, nilai $w_{2}$ sebesar $17,38 \%$ dan nilai $w_{3}$ sebesar -20,38\%. Dengan memasukkan nilai $w_{1}, w_{2}, w_{3}$ dan $w_{4}$ maka diperoleh expected return adalah $(0 \% * 0,4605)+(17,38 \% * 0,3726)+(-20,38 \% * 0,3538)+(3 \% * 0,2450)=$ $1,09386 * 10^{-8} \%$. Karena hasilnya positif, maka portofolio arbitrase telah berhasil diidentifikas i.

Portofolio lama merupakan portofolio dengan tingkat proporsi yang sama. Dalam portofolio yang menggunakan 4 saham maka proporsinya adalah masing-masing $25 \%$. Portofolio yang akan digunakan adalah penjumlahan portofolio lama dengan portofolio arbitrase. Hasilnya dapat dilihat pada Tabel 10.

Tabel 10. Portofolio Optimal yang Terbentuk

\begin{tabular}{|c|c|c|c|}
\hline Proporsi & $\begin{array}{c}\text { Portofolio } \\
\text { Lama }\end{array}$ & $\begin{array}{c}\text { Portofolio } \\
\text { Arbitrase }\end{array}$ & $\begin{array}{c}\text { Portofolio } \\
\text { Optimal }\end{array}$ \\
\hline$w_{1}$ & 0,25 & 0 & 0,25 \\
\hline$w_{2}$ & 0,25 & 0,1738 & 0,4238 \\
\hline$w_{3}$ & 0,25 & $-0,2038$ & 0,0462 \\
\hline$w_{4}$ & 0,25 & 0,03 & 0,28 \\
\hline
\end{tabular}

Berdasarkan Tabel 10 dapat diketahui bahwa investor akan menginvestasikan dananya sebesar $25 \%$ ke saham BRPT, sebesar 42,38\% ke saham BMTR, sebesar 4,62\% ke saham MNCN dan 28\% ke saham BBTN. 


\subsection{Penilaian Kine rja Portofolio}

Penilaian kinerja portofolio bertujuan untuk mengetahui dan menganalisis apakah portofolio yang dibentuk telah dapat meningkatkan kemungkinan tercapainya tujuan investasi. Dalam penelitian ini penilaian kinerja portofolio menggunakan The Sharpe Index dengan rumus

$$
S_{p}=\frac{\bar{R}_{p}-R_{b r}}{\sigma_{p}}
$$

dimana $\overline{\mathrm{R}}_{\mathrm{p}}$ merupakan rata-rata return portofolio, $\mathrm{R}_{\mathrm{br}}$ merupakan return bebas risiko dengan menggunakan data SBI bulan Desember 2017 yaitu 4,25\%. Hasil perhitungan kinerja portofolio dengan menggunakan The Sharpe Index dapat dilihat pada Tabel 11.

Tabel 11. Kinerja Portofolio

\begin{tabular}{|c|c|c|c|c|}
\hline Model & $\overline{\mathrm{R}}_{\mathrm{p}}$ & $\sigma_{\mathrm{p}}$ & $\mathbf{R}_{\mathbf{b r}}$ & The Sharpe Index \\
\hline CAPM & 0,0447 & 0,1202 & 0,0425 & 0,0184 \\
\hline APT & 0,0371 & 0,0917 & 0,0425 & $-0,0590$ \\
\hline
\end{tabular}

\subsection{Perbandingan Kine rja Portofolio}

Semakin besar angka yang diperoleh dari suatu portofolio semakin baik pula portofolio tersebut. Jadi dalam perbandingan portofolio efisien yang dibentuk, portofolio yang memiliki indeks tertinggilah yang optimal. Jika investor ingin menginveatasikan dananya ke portofolio yang terdiri dari empat saham penyusun, maka portofolio yang paling optimal adalah portofolio saham model CAPM. Karena berdasarkan pengukuran kinerja menggunakan indeks Sharpe, dengan mempertimbangkan risiko $\sigma$, nilai indeks Sharpe portofolio model CAPM sebesar 0,0184 lebih besar daripada nilai indeks Sharpe portofolio model APT sebesar $-0,0590$.

\section{KESIMPULAN}

Berdasarkan hasil analisis dan pembahasan yang telah dilakukan, maka dapat diperoleh kesimpulan, yaitu :Menggunakan estimasi parameter MKT diperoleh model regresi sebagai berikut:

1. Portofolio yang terbentuk menggunakan model CAPM dengan 4 saham penyusun yaitu saham PTBA dengan bobot sebesar 0,467\%, BUMI dengan bobot sebesar 12,855\%, BUMI dengan bobot sebesar 53,077\% dan ANTM dengan bobot sebesar $33,601 \%$.

2. Portofolio yang terbentuk menggunakan model APT dengan 4 saham penyusun yaitu saham BRPT dengan bobot sebesar 25\%, BMTR dengan bobot sebesar 42,38\%, MNCN dengan bobot sebesar 4,62\% dan BBTN dengan bobot sebesar $28 \%$.

3. Berdasarkan kinerja portofolio dengan menggunakan The Sharpe Index diperoleh hasil bahwa portofolio dengan model CAPM lebih baik dibanding dengan model APT. Karena nilai indeks Sharpe CAPM sebesar 0,0184 lebih besar daripada APT sebesar $-0,0590$

\section{DAFTAR PUSTAKA}

Ahmad, K. 2004. Dasar-Dasar Manajemen Investasi dan Portofolio. Jakarta: PT Rineka Cipta. 
Anogara, P. dan Pakarti, P. 2006. Pengantar Pasar Modal. Jakarta: PT Rineka Cipta.

Azis, M., Mintarti, S., dan Nadir, M. 2015. Manajemen Investasi. Yogyakarta: Deepublish. idx.co.id. 2017. IDX LQ45. http//www.idx.co.id/Portals/0/StaticData/Publication/ LQ45/20170426_IDX-LQ45-February-2017.pdf. Diakses pada tanggal 21 November 2017.

Isbiyantoro, K., Wulandari, Y., dan Sugito. 2014. "Perbandingan Model Pertumbuhan Ekonomi di Jawa Tengah dengan Metode Regresi Linier Berganda dan Metode Geographically". Jurnal Gaussian. Vol. 3(3), 461-469.

Maruddani, D.A.I. dan Purbowati, A. 2009. "Pengukuran Value at Risk pada Aset Tunggal dan Portofolio dengan Simulasi Monte Carlo". Media Statistika. Vol. 2 (2), 93-104.

Tandelilin, E. 2010. Portofolio dan Investasi. Yogyakarta: Kanisius.

Wibisono, Y. 2009. Metode Statistika. Yogyakarta: Gadjah Mada University Press.

Widarjono, A. 2005. Ekonometrika : Teori dan Aplikasi. Yogyakarta: Ekonisia.

Yahoo! Finance. 2017. Historical Price. http://finance.yahoo.com. Diakses pada tanggal 21 November 2017.

Zulfikar. 2016. Pengantar Pasar Modal dengan Pendekatan Statistika. Yogyakarta: Deepublish. 